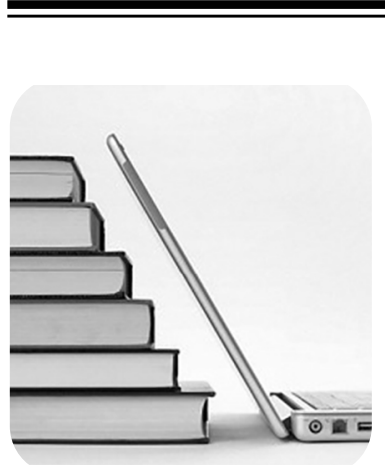

УДК 94(07)

DOI 10.20339/AM.09-21.102

\title{
ОБЗОРЫ。РЕЩЕНЗИИ
}

А.Б. Изюмский, канд. ист. наук, доц.

ГБУ ДПО РО РИПК и ППРО, г. Ростов-на-Дону e-mail: lehrer@inbox.ru

\section{«НОВЫЙ» УЧЕБНИК ДЛЯ ВУЗОВ}

Представлен авторский анализ очередного учебного пособия по курсу истории для средних икол и вузов. Автор обращает внимание на достоинства рецензируемого издания, а также представляет подробный научный анализ содержащихся в пособии недостатков. Сделан вывод о возможности использования нового учебника в образовательном процессе средних учебных заведений и университетов.

Ключевые слова: историческая грамотность, учебный курс, образовательный процесс, учебники для будущих педагогов.

\section{“NEW” TEXTBOOK FOR UNIVERSITIES}

A.B. Izyumsky is Cand. Sci. (History), Ass. Prof. at GBU DPO PO RIPK and PPRO, the City of Rostov-on-Don

Presented is the analysis of a new edition of history textbook for middle schools and universities. The author emphasizes its advantages, and presents detailed scientific analysis of its shortcomings. Conclusion is drawn on the admission of this textbook for middle schools and universities history courses.

Key words: historical literacy, educational course, educational process, textbooks for future pedagogues.

$\mathbf{O}$ б учебниках истории для средних школ пишут сейчас довольно часто, особенно если они привлекут внимание свыше (в частности, после того, как президент В.В. Путин внезапно обнаружил, что в учебнике «Россия и мир», не переиздававшемся уже 8 лет, якобы не упоминается Сталинградская битва). Об учебниках для вузов печать упоминает значительно реже. А жаль, ведь от личности и уровня знаний самого учителя во многом зависит историческая грамотность будущих поколений.

Учебники для будущих педагогов нередко публикуют сами вузы. Одно из таких пособий уже четвертым изданием выпустил и ведущий университет нашей страны МГУ им. М.В. Ломоносова. Речь идет о 4-м издании учебника для студентов высших учебных заведений, абитуриентов и всех интересующихся историей Отечества авторов А.С. Орлова, В.А. Георгиева, Н.Г. Георгиевой, Т.А. Сивохиной.

Все авторы являются сотрудниками МГУ, трое из них имеют степени кандидатов исторических наук, одна (Н.Г. Георгиева) - степень доктора исторических наук. Аннотация уверяет, что издание учебника не только переработано и дополнено, но авторы изложили историю России с древнейших времен до наших дней «с учетом новейших данных, накопленных исторической науки». Так ли это? Похоже, что далеко не всегда.

$\mathbf{K}$ учебнику приложены хронологическая таблица и список руководящих деятелей государства. Судя по таблице, последним значимым событием в истории РФ было заключение договора о совместной антитеррористической деятельности между странами шОС в ноябре 2009 г. (С. 527)1.

\footnotetext{
1 Здесь и далее в круглых скобках указаны страницы рецензируемого издания.
}

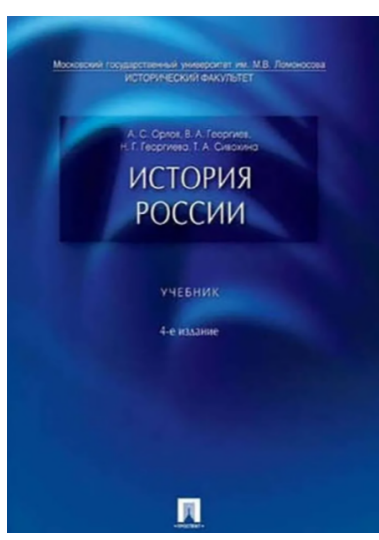

Орлов А.С., Георгиев В.А., Георгиева Н.Г., Сивохина Т.А. История России. 4-е изд., перераб. и доп. Москва: Проспект, 2020. $528 \mathrm{c}$.

Orlov A.S., Georgiev V.A., Georgieva N.G., Sivokhina T.A. History of Russia. 4th ed., reprint. and add. Moscow, 2020.528 p.

ISBN: 978-5-392-31302-0 
Еще раз смотрим на год выпуска «дополненного и переработанного» учебника: действительно, 2020-й. Неужто в списке руководителей президентом до сих пор значится Д.А. Медведев? Нет, авторы все же отметили, что В.В. Путин занимает эту должность с мая 2012 г. «по н. в.». Правда, Д.А. Медведев по-прежнему указан премьером, хотя не является им с января 2020 г., но может просто издательство не успело внести правку в макет?

Оказывается, это не так, потому что последним руководителем Государственной думы «с 2007 г. по н. в.» объявлен Б.В. Грызлов (С. 512), чье «н. В.» на этом посту завершилось еще в декабре 2011 г. Возможно, будущими историками незнание этого обстоятельства тоже будет воспринято как исторический факт, свидетельствующий о реальной роли высшего законодательного органа в политической структуре современной РФ. Думается, однако, что по отношению к нынешним «студентам высших учебных заведений, абитуриентам и всем интересующимся историей Отечества» (С. 2), которым адресует аннотация учебника, такое пренебрежение ближайшей историей выглядит неуважением.

$\Pi$ редисловие к учебнику написано более живым языком, чем основной текст, в нем встречается немало интересных мыслей, принадлежащих, правда, большей частью цитируемым авторам. Привлекает внимание такое, например, изречение: «Ложь в истолковании прошлого приводит к провалам в настоящем и готовит катастрофу в будущем» (C. 3). Жаль только, не сказано, кому это принадлежит.

Само пособие более или менее добросовестно излагает основные события истории от первобытного общества до первого десятилетия XXI в. Плюсом, на наш взгляд, является неоднократное указание авторов на альтернативные позиции ученых по ряду рассматриваемых вопросов, причем чаще всего учебник воздерживается от выражения поддержки определенной позиции. Тем не менее «новейших данных, накопленных исторической наукой» обнаружить в нем нелегко, более того, авторы допускают ряд нечетких, сомнительных и просто ошибочных утверждений. Коснемся некоторых из них, постаравшись не затрагивать оценочных суждений авторов, если они не противоречат установленным историческим фактам.

По поводу происхождения первых русских князей автор (А.С. Орлов) отмечает, что по этому вопросу существуют разные позиции и прямо не выступает в поддержку одной из них. Тем не менее он внезапно разражается целой тирадой:

В современную эпоху вполне доказана научная несостоятельность норманнской теории, объясняющей возникновение Древнерусского государства как результат иноземной инициативы. Однако ее политический смысл представляет опасность и в наши дни. «Норманисты» исходят из положения о якобы исконной отсталости русского народа, который, по их мнению, не способен к самостоятельному историческому творчеству. Оно возможно, как они полагают, только под иноземным руководством и по иноземным образцам [C. 2122].

Непонятно, где автор нашел ученых, считающих, что Древнерусское (как и любое другое) государство могло возникнуть в результате внешней инициативы, а не внутренних общественных процессов. Если такие люди существуют, то учеными они не являются, и их взгляды менее всего могут представлять какую-либо «опасность». Что касается «неспособности русского народа к самостоятельному историческому творчеству», то приписывать подобное мнение «норманистам» (а к ним относились, например, Н.М. Карамзин, М.П. Погодин, С.М. Соловьев, В.О. Ключевский) совсем нелепо. Суть их взглядов только в признании скандинавского происхождения первой русской княжеской династии, что вроде бы не отрицает даже разбираемый учебник.

$\mathbf{P}$ яд высказываний в учебнике не основан на исторических фактах. Например, там некритически, как о чем-то достоверном, пересказывается церковная легенда о паломничестве на русские земли (в Киев и Новгород) апостола Андрея Первозванного (С. 28) (хотя в целом авторы не склонны к повышенной «воцерковленности»). Неубедительно и объяснение прекращения нашествия Батыя в Европе: «Монголы утратили наступательную мощь. Они не могли не считаться с освободительной борьбой, развернувшейся в тылу их войск» (C. 54). Однако о такой «освободительной борьбе» ничего не известно и никаких ее примеров учебник не приводит.

Кстати, говоря об отношениях русских княжеств с соседями, учебник неоднократно пишет об «агрессии» последних. Это слово давно уже внедрилось в учебно-историческую литературу. В ней обычно принято называть «агрессией» действия западных соседей России, здесь же пошли дальше, и учебник пишет также про монголо-татарскую или турецкую агрессию и даже «агрессию джунгар». Между тем, использование подобной терминологии историками выглядит в лучшем случае неоправданным модернизаторством, а в худшем - просто политической конъюнктурой.

Ведь само понятие агрессии появилось только в XX в. и было впервые принято Генеральной ассамблеей ООН в 1974 г. В древности, Средневековье да и в Новое время во всем мире действовали совсем иные представления, и война против более слабого противника воспринималась как неотъемлемое право государства и его правителя. Вероятно, можно не уточнять, что по отношению к России учебник подобных терминов не использует. Если там признается, что Российское государство начало какую-либо войну, то это называется «активизацией внешней политики». 
$\mathbf{H}$ адо отметить, что учебник уделяет много внимания внешней политике, но при этом допускает ряд ляпов. Например, рассказывая о Невской битве 1240 г., автор (А.С. Орлов) утверждает: «Шведы хотели захватить город Старую Ладогу, а затем и Новгород» (С. 55). Ни один источник этого не подтверждает, да и невозможно представить, чтобы такую задачу попытался решить небольшой отряд, который Александр Невский быстро разбил одной лишь «молодшей дружиной». Наиболее вероятным представляется то, что шведы просто хотели собрать дань с населения на спорной в то время территории.

Вслед за тем основной задачей внешней политики России в XVI в. называется «борьба за выход к Балтийскому морю» (С. 80). На самом деле при Иване Грозном этот выход имелся (южное побережье Финского залива), но первый русский царь не собирался строить город в устье Невы (что впоследствии сделал Петр I), а предпочитал захватить у соседей такие богатые порты, как Нарва и Ревель.

Кстати, что касается Нарвы, то с удивлением читаешь, что ее захватили «Речь Посполитая и Швеция» (С. 83). Польша и Швеция в то время были не союзниками, а врагами и никаких совместных действий, конечно, предпринимать не могли. Нарва была занята шведами без всякого участия поляков. О договоре, который царь Василий Шуйский заключил с Швецией, говорится, что в нем «Россия отказывалась от своих претензий на Балтийское побережье, а шведы давали войска для борьбы с Лжедмитрием II» (С. 93). Но в соответствии с договором ни от каких претензий Россия не отказывалась, Швеции только передавался город Корела, который даже не находился на Балтийском побережье.

Вслед за тем учебник утверждает: «Польский король Сигизмунд III объявил, что сам станет русским царем, а Россия войдет в Речь Посполитую» (С. 95). Ничего этого Сигизмунд не объявлял, хотя современники и подозревали его (возможно, небезосновательно) в подобных замыслах. Совсем невнятно сказано о Иване Сусанине: «Символом верности Родине верно служит подвиг костромского крестьянина Ивана Сусанина, пожертвовавшего собственной жизнью в борьбе против польских интервентов» (Там же). А в чем же состоял подвиг? Почему о нем не сказано ничего конкретного, кроме напыщенной фразы? Подытоживая тему «смутного времени», отметим мелкую неточность: утверждение, что атаман Заруцкий и сын Марины Мнишек «были повешены» (С. 96). Повешен был только четырехлетний ребенок, Заруцкого же посадили на кол. Если автор (А.С. Орлов) не хотел упоминать такие ужасы, то мог просто упомянуть, что они были казнены.

C ледующая глава, посвященная русской культуре, в таких словах упоминает самого известного средне- векового русского путешественника: «Хождение за три моря (1466-1472) тверского купца Афанасия Никитина первое в европейской литературе исследование Индии. Свое путешествие Афанасий Никитин совершил за 30 лет до открытия пути в Индию португальцем Васко да Гамой» (С. 119). На самом деле повествование Никитина («исследованием» его вряд ли можно назвать) далеко не «первое в европейской литературе». Задолго до тверского купца немало европейцев посетили Индию и некоторые оставили ее описание. Например, «Четыре книги истории об изменчивости судьбы» Никколо Конти появились в 1444 г., «Описание восточных земель» Одорико Порденоне - в 1330-е гг., а «Послание об Индии» Джованни Монтекорвино и «Книга о разнообразии мира» Марко Поло - в 1292 г.

Другие ляпы относятся уже к следующему XVIII в. Так, в рассказе о Северной войне упоминается «нелепая гибель Карла XII от случайного ядра в Норвегии» (C. 35). Гибель, может, и была нелепой, но последовала она не от ядра, а от пули, точнее, пуговицы, использованной в качестве пули. В описании Семилетней войны содержится утверждение, будто в сражении у деревни Цорндорф «армия Фридриха II была уничтожена» (С. 152). В действительности эта битва не имела решающего результата, но русская армия понесла более тяжелые потери и по приказу командующего Фермора отступила.

Определенные неточности можно обнаружить в рассказе про восстание Е.И. Пугачева, которое, кстати, в традиции советской историографии именуется «крестьянской войной» (большинство современных историков отказалось от подобного определения, т.к. восстание возникло как казацкое, а крестьянство в массовом порядке примкнуло к нему только на последнем этапе). (реди взятых пугачевцами городов называется Кунгур, который правительственные войска сумели удержать. Пугачевские соратники Хлопуша и Белобородов объявлены «работными людьми уральских заводов» (С. 164). Но первый был осужденным каторжником, находившимся в «городовой работе» Оренбурга, а второй - мелким торговцем.

Не отличаются особой точностью и другие исторические события эпохи Екатерины II. Например, не соответствует действительности фраза «Турция, подстрекаемая Францией и Англией, осенью 1768 г. объявила войну России» (С. 172). Это утверждение явно из традиционных представлений о «коварной англичанке». Франция действительно была турецким союзником (хотя конкретные факты ее «подстрекательства» нигде не названы), но Англия находилась тогда в хороших отношениях с Россией, и немало британских морских офицеров даже участвовало в войне на кораблях русской средиземноморской эскадры (они были отправлены по просьбе Екатерины II правительством Великобритании). 
Из давних мифов взято лаконичное письмо А.В. Суворова с ультиматумом коменданту Измаила, так же как и ответ паши (С. 173-174). Сохранившийся официальный текст письма выглядит совсем иначе, но цитируют его крайне редко (разве что в академических научных изданиях), видимо, потому что яркость предпочитают достоверности. Определенным преувеличением представляется заявление, что «в сражении у мыса Калиакрия турецкий флот был уничтожен» (С. 174). Сражение завершилось победой русского флота, но говорить об уничтожении врага вряд ли возможно, т.к. ни один турецкий корабль не был потоплен (хотя многие повреждены).

Кстати, перечисляя города, построенные на отвоеванных у турок землях, учебник называет Екатеринослав, уточняя «ныне Днепропетровск» (С. 173), тогда как с 2016 г. город называется Днепр. Наконец, нельзя не отметить бессмысленность следующей фразы: «В России, в отличие от колониальных империй Западной Европы, имевших заморские территории, русское население жило бок о бок с присоединенными к империи народами» (С. 177). Во-первых, заморские колонии имела и Россия, в частности Аляску и форт Росс. Во-вторых, непонятно, в чем здесь российская особость, т.к. везде колонизаторы и колонисты живут рядом с присоединенным населением. Например, рядом с американскими индейцами жили испанские поселенцы, британские фермеры, французские трапперы, американские ковбои и др.

$\mathbf{H}$ екоторых уточнений заслуживает и рассказ учебника о войнах следующего века. Говоря об Отечественной войне 1812 г., авторы (В.А. и Н.Г. Георгиевы) подчеркивают преимущество Наполеона, утверждая, что «первый эшелон войск, вошедших в пределы России, насчитывал 450 тыс. человек, тогда как русских на западной границе было около 210 тыс. человек» (С. 211). Здесь не учитывается, что многие подразделения «Великой армии» были намного меньше официального списочного состава (особенно в войсках союзников). Что же касается противостоявших им русских армий, то 1-я и 2-я армия насчитывали 153 тыс., 3-я - 45 тыс., а Дунайская армия (правда, вступившая в дело позже) - 55 тыс. Кроме того, под Ригой находился 18-тысячный корпус Эссена, противостоявший французскому корпусу Макдональда и пруссакам.

Едва ли можно согласиться с тем, что после Бородинского сражения «М.И. Кутузов, вопреки общему мнению генералов, принял решение оставить Москву» (С. 213). Мнение генералов на военном совете в Филях отнюдь не было «общим». Большинство действительно высказалось за новое сражение, но несколько человек поддержало решение об отступлении. Кутузов согласился с мнением меньшинства, на что как командующий имел полное право.
Не представляется уместным пафосное высказывание этих же авторов, что Крымская война «продемонстрировала героизм и непоколебимый дух русского народа» (С. 222). Мужество солдат и моряков не идентичны «духу народа». Крымская война не воспринималась обществом как отечественная, а широкие массы народа вообще не приняли в ней никакого участия (кроме поставки рекрутов). В рассказе о русско-турецкой войне 1877-1878 гг. учебник делает ошибку, которую заметил бы, вероятно, чуть ли не каждый болгарский школьник: «И.В. Гурко был вынужден обороняться на Шипкинском перевале с июля по ноябрь 1877 г.» (C. 265). Генерал Гурко действительно занял перевал, но затем воевал на других участках фронта, а оборону Шипки несли части под командованием генерала Ф.Ф. Радецкого (считается национальным героем Болгарии).

$\mathbf{E}$ ще серьезнее делаются ошибки, когда учебник переходит к войнам XX в. Рассказывая о бое на рейде Чемульпо крейсера «Варяг» и канонерки «Кореец» с японской эскадрой, авторы (В.А. и Н.Г. Георгиевы) категорически утверждают, что «кораблям противника были нанесены серьезные повреждения, а один японский крейсер потоплен». Но никакие японские крейсера, как и другие корабли, не были потоплены или повреждены, более того, в них не удалось добиться ни одного попадания.

Причины простые: комендоры «Варяга» при всем своем мужестве оказались плохо обучены, а орудия «Корейца» не обладали достаточной дальнобойностью. Это установлено по архивным документам и опубликовано исторической комиссией морского генштаба еще в 1912 г. Следом идет еще одна ошибка, когда сообщается: «Русских моряков приняли на борт английские, французские и американские корабли» (С. 313). Слово «американские» было бы правильней заменить на «итальянские», поскольку командир американской канонерки отказался принять матросов с «Варяга», ссылаясь на отсутствие разрешения своего начальства.

Наконец, говоря о судьбе Порт-Артура, учебник отмечает: «Крепость была сдана (декабрь 1904 г.) в результате предательства коменданта генерала Стесселя» (Там же). Прежде всего приходится отметить, что Стессель был не комендантом крепости (эту должность занимал генерал К.Н. Смирнов), а начальником Квантунского укрепленного района. А затем нельзя не признать, что его действия, приведшие к сдаче крепости до полного исчерпания возможности обороны, можно расценить как проявление трусости и бездарности, но все же не предательство, которое предусматривает сознательный переход на сторону противника. В последнем Стесселя не обвиняли даже его враги.

Кстати, предательство мерещится авторам и на другой войне - Первой мировой. Тогда, как уверяет учебник: «Мно- 
гие высокопоставленные чиновники были заподозрены (и не без оснований) в шпионаже и государственной измене» (C. 329). Фамилии при этом не называются и неудивительно: ни во время войны, ни столетие спустя не выявлено ни одного случая шпионажа и государственной измены какого-либо высокопоставленного чиновника Российской империи.

Впрочем, в рассказе о Первой мировой войне, кроме этого голословного заявления, допущена лишь одна неточность при описании событий 1914 г. в Восточной Пруссии: «Усиленные германские части, воспользовавшись несогласованностью действий 1-й и 2-й русской армии в Восточной Пруссии, нанесли им тяжелое поражение» (С. 317). Прилагательное «усиленные» здесь явно лишнее, т.к. 2-я армия Самсонова была разбита раньше, чем к немцам подошли переброшенные с Западного фронта два корпуса и кавалерийская дивизия.

$\mathbf{P}$ оссийские революции авторы изображают в целом с позиций, близких к советской историографии, а кое в чем идут и дальше. В частности, во время «кровавого воскресенья» 1905 г., по словам учебника, «было убито более 1200 человек и около 5 тыс. ранено» (С. 301). Непонятно, откуда взяты эти цифры, т.к. даже официальные советские издания обычно называли цифру 4600 убитых и раненых, взятую из статьи В.И. Ленина.

Реальное же число жертв было значительно меньше: по официальным данным, 130 убитых и около 300 раненых, а по подсчетам советского историка В.И. Невского - от 150 до 200 убитых и от 450 до 800 раненых. Конечно, главной революционной силой признается рабочий класс. С этим спорить нет оснований, но численность его еще более завышается, чем в школьных учебниках. Сначала авторы уверяют, что пролетариат «к 1913 г. составлял около 19\% населения» (С. 293), причем, судя по контексту, под этим понятием подразумеваются только фабрично-заводские рабочие, но затем появляется «уточнение»: «Рабочий класс (18 млн человек) состоял из городских и сельских пролетариев» (С. 332). Если перевести проценты в цифры, то они не сходятся даже между собой.

Революция 1917 г. показана в целом без серьезных искажений, но один эпизод все же содержит ошибку утверждение, будто 26 февраля 1917 г. «гвардейцы Павловского полка, поддержав рабочих, открыли огонь по полиции» (С. 329). Никакого огня солдаты не открывали. Инцидент заключался в том, что одна полурота отказалась разгонять демонстрантов, после чего была арестована и отправлена в Петропавловскую крепость.

Приход к власти большевиков ознаменован характерным умолчанием: идеология этой партии описана очень сжато, а о ее краеугольном камне - идее мировой социалистической революции, которой должен положить начало «великий октябрь», не сказано ни слова. Такому важнейшему инструменту коммунистического революционного движения, как Коминтерн, посвящен только небольшой абзац в главе о внешней политике СССР 1920-1930-х гг.

Непонятно и следующее утверждение учебника, касающееся гражданской войны:

В 1919 г. был создан план одновременного удара на советскую власть с востока (А.В. Колчак), юга (А.И. Деникин) и запада (Н.Н. Юденич). Однако осуществить комбинированное наступление не удалось (С. 350).

Кем был создан этот план - учебник не уточняет. Да и вряд ли это возможно, т.к. белые генералы действовали разобщенно, единого командования не имели и составлять такие планы было просто некому.

Говоря об экономической политике СССР, один из авторов (Т.А. Сивохина) утверждает следующее:

Зимой 1932-33 гг. многие только что коллективизированные хозяйства охватил голод, от которого умерло, по разным данным, от 3 млн до 5 млн человек (точная цифра неизвестна, информация о голоде тщательно скрывалась) (С. 369).

Точная цифра действительно неизвестна, но варьируется она совсем в других диапазонах. Государственная дума РФ в своем заявлении к 70-летию голода упомянула о 7 млн погибших. А труды д. и. н. В.В. Кондрашина и документальный трехтомник «Голод в СССР» называют еще большие цифры. Непонятно, что мешало автору ознакомиться хоть с некоторыми из этих работ. И уж совсем неясно, из какого источника, кроме авторской фантазии, могла быть заимствована фраза: «Многие представители эмиграции вернулись в конце 30-х годов на родину» (С. 399). Более или менее массовым стало возвращение эмигрантов после гражданской войны, а приезд в конце 1930-х гг. отдельных из них (например, А. Куприна или М. Цветаевой) носил единичный характер.

$\mathbf{H}$ е может не вызвать замечаний ряд положений учебника, относящихся к обстановке в СССР накануне Великой Отечественной войны. Порой создается впечатление, что они заимствованы даже не просто из советского периода, но конкретно из каких-то брошюр 1960-х гг. По крайней мере, в более позднее время сложно было бы встретить заявление, что советская «политика в области вооружений имела отстающий от Запада и в первую очередь от фашистской Германии характер» (С. 379). Ведь давно уже (задолго даже до выхода первых изданий учебника) опубликованы документальные данные о советских вооружениях той эпохи, объемы которых намного превышали к 1939 г. западные. 
Одних танков тогда Красная Армия имела больше, чем все армии Запада.

Однако учебник игнорирует этот факт и именно слабостью СССР объясняет заключение известного пакта Молотова-Риббентропа:

Советскому правительству было известно, что германская армия уже находится в полной готовности для нападения на Польшу. Понимая неизбежность войны и свою неготовность к ней, оно резко изменило внешнеполитическую ориентацию и пошло на сближение с Германией (С. 388).

Авторы (В.А. и Н.Г. Георгиевы) словно забыли, что страницей раньше они писали, как осенью 1938 г. СССР перебросил к западной границе 30 дивизий, готовясь вступить в военные действия на стороне Чехословакии, и этого не произошло только потому, что правительство Бенеша отказалось от помощи. (Тоже, кстати, довольно спорный вопрос. Чехословацкое правительство запросило Москву о возможности военной помощи, но не получив ответа в ближайшие часы, отказалось от запроса и приняло Мюнхенское соглашение.) Получается, что осенью 1938 г. СССР был вполне готов к войне с Германией, а летом 1939 г. эта готовность куда-то исчезла. Вопрос о том, была ли тогда сама Германия готова к такой войне, в учебнике, разумеется, не затрагивается.

Затем авторы сообщают о присоединении к СССР балтийских республик в следующих выражениях:

В этих республиках в условиях присутствия советских войск были проведены выборы в законодательные органы, на которых одержали победу коммунистические силы. В 1940 г. Эстония, Латвия и Литва вошли в состав СССР (Там же).

Интересно, над кем же «одержали победу коммунистические силы», если никто, кроме них, к «выборам» допущен не был? Сами над собой?

C ледующая тема, поднятая теми же авторами, касается причин серьезных поражений Красной Армии в первые месяцы войны. Вопрос этот следовало бы признать сложным, т.к. ответ на него в первую очередь подразумевает объяснение, почему СССР не смог использовать имевшееся накануне войны серьезное превосходство над гитлеровской Германией в людских резервах, военной технике и экономическом потенциале. Как правило, учебная литература избегает подобных объяснений. Не являются исключением и авторы данного учебника.

Они выделяют четыре причины неудач. К первой относится то, что «Германия имела значительные экономические и военно-стратегические преимущества». Выражались они в том, что она «использовала не только свои, но и ресурсы союзнических, зависимых и оккупированных стран Европы»
(C. 400). Оставив в стороне тот факт, что возможность использовать ресурсы других стран появилась у фашистов во многом благодаря соглашению 1939 г. с СССР, отметим, что даже после этого Советский Союз сохранял превосходство по большинству параметров.

Далее, по мнению авторов, немецкие войска «имели опыт ведения войны и широких наступательных операций» (Там же). Вообще-то, определенный опыт имела и Красная Армия, тем более что ее давно готовили к большой войне. В качестве третьей причины называется то, что «техническое оснащение вермахта (танки, авиация, средства связи и др.) значительно превосходили советские» (С. 401). Это просто неправда, придуманная несколько десятилетий назад и опровергнутая многочисленными документальными публикациями. Ни в авиации, ни в артиллерийском и стрелковом вооружении, ни тем более в танках вермахт Красную Армию не превосходил. Наконец, упоминается неверие Сталина в начало войны летом 1941 г. «Поэтому вся страна и в первую очередь армия, ее руководство не были подготовлены к отражению агрессии» (Там же). Такое утверждение также является только повтором придуманных после XX съезда КПСС доводов, которые с натяжкой могли бы объяснить неудачи первых дней войны, но никак не все последующие события.

B параграфе о самой Великой Отечественной войне серьезных ошибок нет, но хотелось бы уточнить текст, затрагивающий помощь союзников:

\footnotetext{
Поставки по так называемому ленд-лизу боевой техники, медикаментов и продовольствия не имели решающего значения (по разным данным от 4 до $10 \%$ произведенной в нашей стране продукции) но оказали определенную помощь советскому народу в наиболее трудный период войны (С. 408).
}

Здесь необходимо отметить, что роль ленд-лиза различалась в разных областях. Приведем некоторые факты (поскольку в публикациях встречаются разные цифры помощи, возьмем лишь наименьшие). В области транспорта союзники поставили автомобилей в 1,5 раза больше, чем произвела советская промышленность в годы войны. Паровозов было поставлено в четыре с лишним раза больше советского производства, а вагонов в десять с лишним раз. Поставки средств связи позволили только в 1942-1943 гг. оснастить радиостанциями 150 дивизий, а полевыми телефонами - 329 дивизий. Большая часть самолетов и основная масса танков были советского производства, но для тех же самолетов и танковых моторов необходим алюминий. За годы войны алюминия нашей стране поставили, по разным оценкам, от 106 до 125\% от советского производства. Поставки продовольствия, возможно, не имели для 
армии критического характера (хотя пресловутой тушенки было поставлено 108\% от советского производства), но они спасли фактически от голодной смерти многих людей в советском тылу.

Впрочем, о значении союзнической помощи достаточно определенно высказался не кто иной, как «маршал Победы» Г.К. Жуков:

Но ведь нельзя отрицать, что американцы нам гнали столько материалов, без которых мы бы не могли формировать свои резервы и не могли бы продолжать войну... У нас не было взрывчатки, пороха. Не было чем снаряжать винтовочные патроны. Американцы по-настоящему выручили нас с порохом и взрывчаткой. А сколько они нам гнали листовой стали! Разве мы могли бы быстро наладить производство танков, если бы не американская помощь сталью? А сейчас представляют дело так, что у нас все это было свое в изобилии (См.: Будницкий О. Люди на войне. М., 2021, С. 180).

То, что Жуков отмечал такие факты не в своих официальных мемуарах (где это было невозможно по цензурным причинам), а в частном разговоре, прослушанном и записанном КГБ, нисколько не снижает достоверности приведенных сведений.

Наконец, заканчивая раздел о войне, учебник небрежно упоминает, что в 1945 г. «в течение месяца Япония потерпела сокрушительное поражение» (С. 415). Откуда взялся этот «месяц»? Официально советско-японская война длилась около трех недель, но фактически активные военные действия завершились еще раньше (на другой день после ее объявления японское правительство дало предварительное согласие капитулировать, а через шесть дней объявило о капитуляции официально).

$\mathbf{P}$ ассказывая о некоторых особенностях послевоенной истории СССР, учебник порой проявляет поразительное незнакомство с реалиями советской жизни. В частности, рассказывая о реформах Н.С. Хрущева, автор (Т.А. Сивохина) пишет:

Недовольство вызвало проведенное в 1962 г. разделение местных советов по производственному принципу на промышленные и сельские. Эта реорганизация нарушила единство власти, смешала функции органов местного самоуправления (С. 428).

В действительности реорганизация затрагивала не «местные советы», а партийные органы, что, по замыслу ее инициатора, должно было усилить роль партии в экономике. Ну, а городские и сельские советы существовали в стране как до, так и после неудачной реформы.

Возможно, опечаткой является фраза о выводе советских войск из Афганистана в 1988 г. вместо 1989 г. (С. 460). Но эта опечатка повторяется во всех изданиях. Наконец, переходя к распаду социалистической системы, учебник сообщает, как «в результате свободных выборов была отстранена от власти правящая партия в Польше» (С. 461). Этот процесс носил все же более сложный характер. На выборах 1989 г. оппозиции было разрешено выдвигать кандидатов только в 35\% избирательных округов. Но после ее громкой победы почти во всех этих округах ряд депутатов, поддерживавших ранее власть, отказался делать это дальше, и коммунистическое руководство было вынуждено уйти в отставку.

O постсоветском периоде РФ, отметим в заключение, вряд ли есть необходимость много писать, т.к. общим правилом учебной литературы является здесь четкое следование в русле официальных установок. Но даже в этих рамках есть определенные нюансы, в частности нежелательно прямое отрицание общеизвестного. В рецензируемом учебнике такое встречается.

Например, рассказывая о заключении соглашения 1997 г. между РФ и странами НАТО, учебник упоминает только о содержащемся там отказе от применения силы. Но вслед за тем негодующе восклицает: «Однако очень скоро руководство стран НАТО нарушило взятые обязательства» (С. 476). Неужели эти страны напали на РФ? Нет, но стали принимать в свою организацию государства Восточной Европы. Можно сколько угодно возмущаться распространением НАТО на Восток, однако связывать это с некими «обязательствами», никогда не дававшимися, является заведомым искажением недавней истории.

Подводя итог, нельзя не обратить внимание на самый последний раздел учебника, посвященный «духовной жизни современной России» (С. 508-509). Он больше всего сообщает о возрастающей роли в «воспитании высоконравственного человека» так называемых «традиционных конфессий России», о вложениях в науку из федерального бюджета, о продолжающейся публикации представителей Российского зарубежья 1920-1930-х гг. Из современных же деятелей культуры упоминаются только Н. Михалков, И. Глазунов и З. Церетели. Если это самая яркая часть современной «духовной жизни», то остается только слегка перефразировать слова Е. Замятина, сказанные ровно сто лет назад: «Я боюсь, что у русской культуры одно только будущее: ее прошлое».

Но будем надеяться, что реальная русская культура при всех проблемах намного богаче, чем может показаться из учебника. Что касается последнего, то он, очевидно, ничем не выдается к лучшему из общей массы учебной литературы. Можно только пожалеть, что такая «кузница кадров», как МГУ, дает ему свою марку, даже не попытавшись оказать помощь элементарным редактированием. 